\title{
Population structure, growth and fishery yield of Leporinus acutidens (Valenciennes, 1837) (Teleostei: Anostomidae) in Yacyretá Reservoir (Argentina)
}

\author{
Patricia R. Araya ${ }^{1}$, Angelo A. Agostinho ${ }^{2}$ and José A. Bechara ${ }^{3}$
}

\begin{abstract}
The population structure and dynamics of Leporinus acutidens (Valenciennes, 1837), upstream from Yacyretá Dam (Upper Paraná River, Argentina) were analyzed for their relation to age, condition factor, growth, mortality and fishery yield. The pre(1990-94) and post- (1995-98) filling phases of the reservoir were compared with regard to age structure, condition factor, and the length/weight relationship of fish. Fish sampling was carried out at four sampling sites following a longitudinal gradient along the river. The catches took place monthly using eight monofilament gillnets (mesh 40 to $160 \mathrm{~mm}$ ). The growth marks on the scales were annual (9-year maximum). The study of the variation in the monthly averages of the scale marginal increments revealed that the period of the growth ring formation shifted from winter to spring in the post-filling phase. The length/weight relationship coefficient $(b)$ was higher after dam closing. The condition factor increased before the reproduction period and during late summer, reaching maximum values in the post-filling phase, and especially at the sampling site placed within the reservoir region. The von Bertalanffy growth coefficient $k$ for both sexes was 0.16 , and the asymptotic length $L$ " reached 338 $\mathrm{mm}$. Natural mortality during the whole study period, according to Pauly's equation, was 0.25 years ${ }^{-1}$ and total mortality was 0.37 years $^{-1}$. The Beverton-Holt yield per recruit $(Y / R)$ model attained $57.23 \mathrm{~g}$, with a maximum sustainable yield $(M S Y)$ of 70.75 g. Low total mortality was associated with the lack of commercial exploitation of the species.
\end{abstract}

A população de Leporinus acutidens (Valenciennes, 1837), a montante da barragem de Yacyretá (Alto Paraná, Argentina) foi analisada em relação à idade, crescimento, condição nutricional, mortalidade e rendimento da pesca, sendo realizadas comparações na estrutura etária, condição nutricional e relação peso-comprimento nos períodos pré (1990-94) e pós (1995-98) represamento. As amostragens foram conduzidas em quatro localidades ao longo do rio. As capturas foram realizadas mensalmente com oito redes monofilamento (malhagens de 40 a $160 \mathrm{~mm}$ ). Os anéis de crescimento nas escamas são formados anualmente (máximo 9 anos). A análise das variações mensais na média do incremento marginal das escamas revelou que o período de formação dos anéis de crescimento alterou do inverno para a primavera após o represamento. Já o coeficiente da relação peso/comprimento (b) foi maior, para ambos os sexos, após o represamento. $\mathrm{O}$ fator de condição apresentou-se mais elevado antes do período reprodutivo e no final do verão, alcançando valores máximos após o represamento, especialmente em locais dentro do reservatório. O valor do coeficiente $k$ da curva de crescimento de von Bertalanffy foi 0.16 e o comprimento assintótico $L$ " alcançou $338 \mathrm{~mm}$. A mortalidade natural, estimada a partir da equação de Pauly, foi de 0.25 year $^{-1} \mathrm{e}$ a mortalidade total de 0.37 year $^{-1}$. O rendimento por recruta, estimado pelo modelo de Beverton-Holt $(Y / R)$ atingiu $57.23 \mathrm{~g}$, com um rendimento máximo sustentável (RMS) de $70.75 \mathrm{~g}$. A baixa mortalidade total foi associada com a inexistência de uma exploração comercial relevante do estoque.

Key words: Age, Mortality, Dam, Paraná River.

\section{Introduction}

The diversity of the neotropical ichthyofauna is threatened by the growing complexity of the human activities affecting continental waters: irrigation; industry; sewage; navigation; hydroelectric power generation; and others.
Growing energy demands and technological development have fostered the construction of large hydroelectric dams that have changed the dynamics of water courses, causing upstream and downstream impacts (Ward \& Stanford, 1979; Petts, 1984; Nilsson et al., 2005; Agostinho et al., 2007).

The physical, chemical, and biological modifications

${ }^{1}$ Facultad Cs. Ex. Qcas. y Nat. - UNaM - Félix de Azara 1552 (3300) Posadas. Argentina. araya@fceqyn.unam.edu.ar ${ }^{2}$ NUPELIA-UEM- Av. Colombo, 5790; CEP:87100-900, Maringá. Brasil. agostinhoaa@nupelia.uem.br ${ }^{3}$ in memoriam - Instituto de Ictiología del Nordeste. Fac. Cs. Veterinarias-UNNE and CONICET, Corrientes, Argentina. 
caused by the construction of a dam trigger a series of responses from aquatic communities. In fish, the proliferation of sedentary species and reduction or elimination of potamodromous species have been demonstrated (Agostinho et al., 2007). Therefore, those species having better adaptations to the new conditions will colonize the novel environment of the fluvial lake (Agostinho et al., 1999).

Leporinus acutidens is a representative of the family Anostomidae, common to the waters of the Paraná River basin, that inhabits mainly lotic environments, although it may also be found in certain lentic habitats (Lopes et al., 2000; Petry et al., 2003; Okada et al., 2003) in Brazil, Argentina and Paraguay (Bechara et al., 1999). It has modified its reproductive tactics and successfully reproduced in reservoirs, including small ones such as Lobo Dam (Barbieri \& Santos, 1988).

Most authors have considered this species a synonym for L. friderici (Bloch, 1794). However, in this work, the name L. acutidens was maintained according to Braga (1993).

There are several studies on L. acutidens that deal with ecological and biological aspects: Souza Braga (2001) in Volta Grande Reservoir (Brazil); Godoy (1975) in Mogi Guaçu River (Brazil); Andrian et al. (1994) in high Paraná River (Brazil); and Boujard et al. (1991) in French Guiana. It has been characterized as migratory (Godoy, op. cit.), with omnivorous feeding habits and a tendency toward herbivory (Hahn, 1998). However, Agostinho et al. (2004) did not include it among migratory fishes in the high Paraná basin. Moreover, this species had a diet based on fish and terrestrial plants during the first years after the closing of the Corumbá reservoir, according to both stomach contents and stable isotope analysis (Luz-Agostinho et al., 2006; Pereira et al., 2007).
A revision of the genus Leporinus carried out by Garavello (1979) using specimens from the Paraná basin (Brazil) reveals that $L$. copellandii (Steindachner, 1875) is a synonym for $L$. friderici, the name being adopted by some Brazilian researchers.

The main objective of this study was to evaluate the population response of $L$. acutidens to the change in biotope that resulted from the construction and functioning of Yacyretá Hydroelectric Dam (Upper Paraná River), making a comparison between the phases previous to and after the filling of the reservoir (76 $\mathrm{m}$ asl), with regard to age, length/weight, size-structure, and condition factor. A second aim dealt with the analyses of growth and mortality, as well as a simulation of the fishery yield during the whole study period.

\section{Materials and Methods}

According to its main biotic and abiotic characteristics, the Paraná River can be divided into four sections: Paraná Superior; Alto Paraná; Paraná Medio; and Paraná Inferior (Bonetto, 1986). The study area is located in Alto Paraná, at the border of Paraguay with the Argentinean provinces of Misiones and Corrientes, in a zone that has been modified by the construction of the Yacyretá Dam $\left(27^{\circ} 28^{\prime} \mathrm{S}, 56^{\circ} 44^{\prime} \mathrm{W}\right)$. It is a lowland dam, characterized by a short water residence time ( 3 to 7 days). The surface of the reservoir is approximately $120 \mathrm{al} .0 \mathrm{~km}^{2}$ (at $76 \mathrm{~m}$ asl), with an estimated volume of 7000 $\mathrm{hm}^{3}$, an average depth of $14 \mathrm{~m}$, and a maximum depth of $23 \mathrm{~m}$. The reservoir was filled between April and August 1994 (García, 1999).

The samplings were carried out upstream from the dam at the following sites: a) Mouth of Yabebiry Stream, a tributary

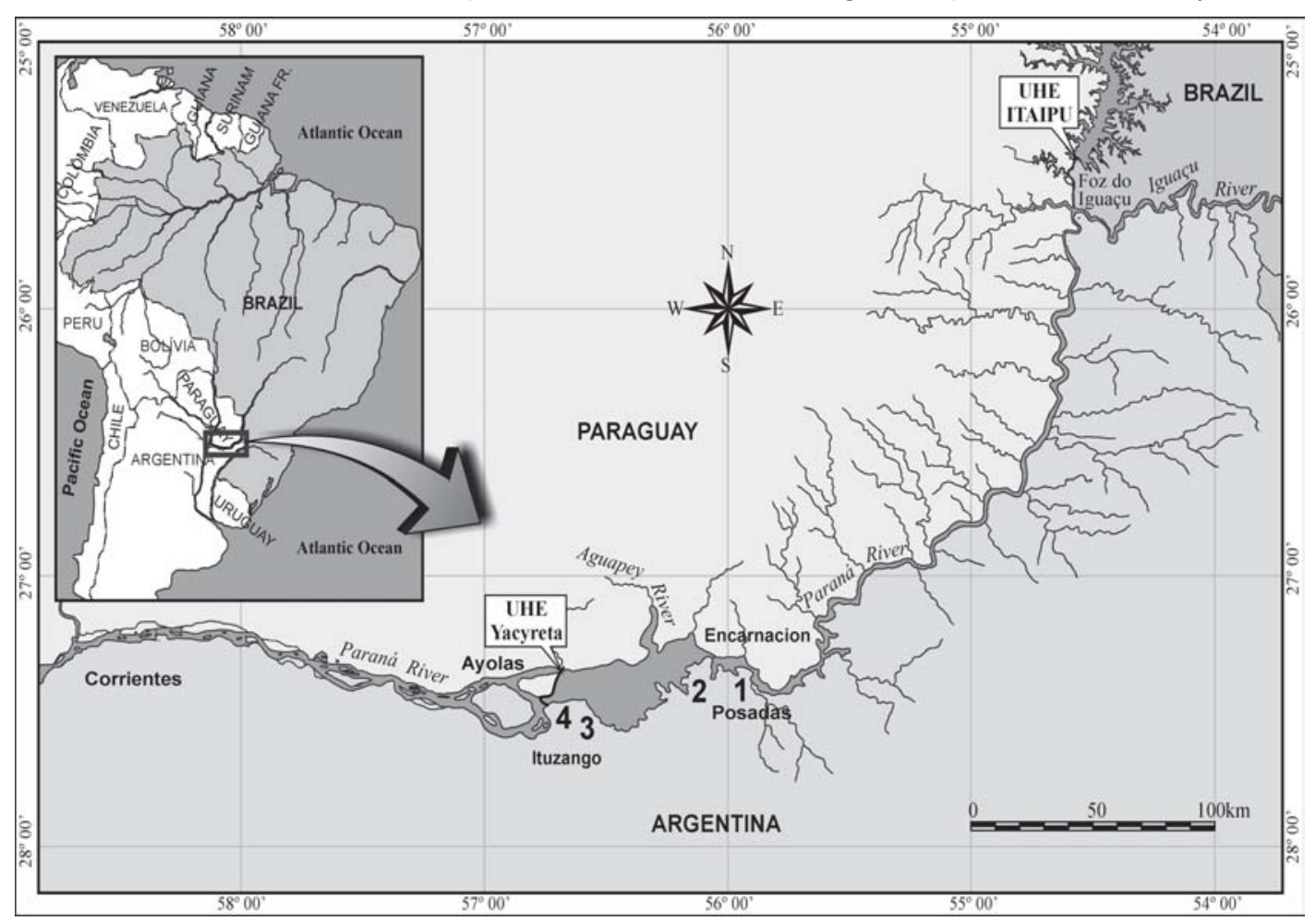

Fig. 1. Sampling area. 1- Yabebiry Stream; 2- Nemesio Parma; 3- Puerto Valle, 4- Puerto Júpiter. 
of the Paraná River, located $1625 \mathrm{~km}$ upstream of its embouchure in the Río de La Plata $\left(27^{\circ} 18^{\prime} \mathrm{S} 55^{\circ} 35^{\prime} \mathrm{W}\right)$; b) Vicinity of Nemesio Parma, an Argentine Coast Guard detachment, placed $1570 \mathrm{~km}$ upstream of the mouth $\left(27^{\circ} 20^{\prime} \mathrm{S} 56^{\circ} 00^{\prime} \mathrm{W}\right)$, in the upper region of the reservoir, with major fluvial influence; c) Puerto Valle, at $1510 \mathrm{~km}$ upstream of the mouth (27036'S $\left.56^{\circ} 25^{\prime} \mathrm{W}\right)$, located in the lacustrine section; and d) Puerto Júpiter, at $1478 \mathrm{~km}$ upstream $\left(27^{\circ} 28^{\prime} \mathrm{S} 56^{\circ} 44^{\prime} \mathrm{W}\right)$, the site located closest to the dam (Fig. 1).

The material comes from experimental fishery campaigns carried out by the Regional Project on Fish Biology (CIDETFaculty of Sciences, National University of Misiones, Argentina), in agreement with the Yacyretá Power Dam facility (EBY).

Eight panels of monofilament gillnets (mesh 40, 50, 60, 70, $80,120,140$ and $160 \mathrm{~mm}$ ) measuring $15-30 \mathrm{~m}$ long and $2-3 \mathrm{~m}$ in height were used in the catches. At each sampling site, the nets remained submerged for 48 hours and the fish captured were extracted every 8 hours. The nets were placed in areas near the coast of the river or reservoir.

Sampling took place monthly in autumn and winter and every 20 days in spring and summer during the following periods: April 1990 - March 1991; May 1993 - April 1994; July 1994 - August 1995; and February 1996 - December 1998.

The total catches of $L$. acutidens reached 848 individuals. The following data were recorded for each specimen: net of origin; total weight $(T W)(\mathrm{g})$; standard length $(S L)(\mathrm{mm})$; height (m); sex; and macroscopic stage of gonads. The scales of 360 individuals of both sexes were obtained, covering the range of captured lengths. The scales were removed from the area immediately behind the insertion of the pectoral fins. They were put in paper bags and duly identified.

In the laboratory, the scales were washed using a 7\% sodium hypochlorite solution and a brush (to eliminate the soft tissue - tegument), then dried in an oven at $20^{\circ} \mathrm{C}$. A large number of scales $(>10)$ per specimen were observed under a magnifying glass in order to choose those in good condition, discarding the asymmetric and regenerated scales. Four or five were then mounted between two slides.

A stereoscopic microscope (6X) and transmitted light were used for the age reading. Employing a micrometric ocular, the distance from the focus to the edge of the scale was measured (in $\mathrm{mm}$ ) $(R)$, as well as each distance from the focus to the different growth marks $(R n)$, along a line that formed a $40^{\circ}$ angle with the anterior-posterior axis.

The relationships among the marginal increment over the annual cycle and the environmental variables of surface water temperature and mean hydrometric level were analyzed. The daily water level registers (Argentine Coast Guard - Puerto Posadas) were averaged for each month during the entire study period (Fig. 2). Water temperature was recorded once or twice a month on dates corresponding to the fishing field trips. The entries were averaged for each month (1990-1998).

With the aim of verifying the existence of changes in the population structure, the data were grouped into two phases. The first corresponded to the stage before the filling of the reservoir (60 m asl) (April 1990 to December 1994). The second corresponded to the period after the filling $(76 \mathrm{~m}$ asl) (January 1995 to December 1998).

The growth marks on L. acutidens are shown by the interruption of the growth circles on the entire scale, as on most temperate water fish (Payne, 1976).

Only those marks that covered the entire scale were considered, and in the case of double marks or those difficult to interpret, the sample was discarded. The number assigned to each age class corresponded to the number of marks.

In order to validate the determination of the ages and estimate the time of growth ring formation, the average monthly variation in the marginal increment of the scales $(M I)$

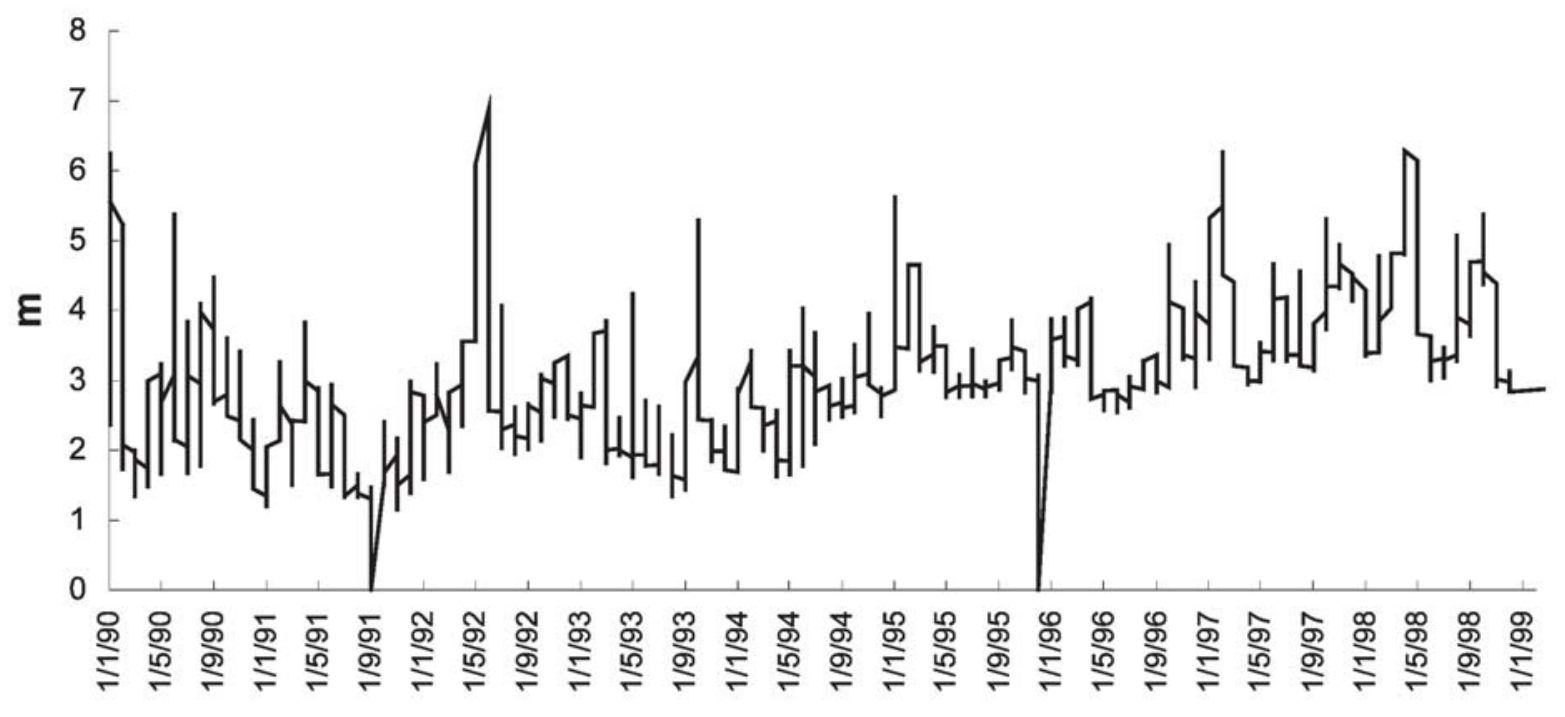

Fig. 2. Water levels of the Paraná River at Posadas (Argentina). Values represent monthly average water levels between January 1990 and January 1999. 
(Matsuura, 1961) was used. The $M I$ is represented by the following expression:

$$
M I=\left(R-R_{n}\right) /\left(R_{n}-R_{n-1}\right)
$$

where: $R=$ total radius of the scale measured using a micrometric ocular; $R_{n}=$ radius of the scale at age $n$; and $R_{n-1}$ $=$ radius of the scale at age $n-1$.

The smallest average marginal increment indicates the formation time of the rings (Heald \& Griffiths, 1967). Therefore, the period in which the frequency of scales with an age ring on the edge is the greatest is considered the formation time of the growth mark.

It was found that in any stage of the life of a fish, weight varies directly with length (King, 1995) following the expression:

$$
T W=a * S L^{b}
$$

where: $T W=$ total weight $(\mathrm{g}) ; S L=$ standard length $(\mathrm{mm})$; and $a$ and $b$ are regression parameters.

In order to establish the length-weight relationships, the aforementioned equation was adjusted for males and females separately and for both sexes into a single analysis. Curve fitting was carried out separately for the pre- and post- reservoir filling phases.

The constants $a$ and $b$ were adjusted using non-linear regression by means of the iterative method of Marquart (Saila et al., 1988; Bervian \& Fontoura, 2006) (Statgraphics - Graphics Software Systems, Inc., 1990). To test for the significant difference of the value $b$ from 3 (alometric growth), a twotailed one-sample $t$-test was employed using the following expression:

$$
t=\frac{b-3}{S x}
$$

where $S x=$ standard error of $b$ with n-1 d.f.

In order to adjust the equations, total catch data were used. The length-weight relationship curves were compared between both filling phases and sexes separately using an analysis of covariance (ANCOVA) to determine the significance of the difference in the parameters $a$ and $b$. The latter was evaluated by means of the test of parallelism included in the ANCOVA.

With the purpose of establish the physiological conditions of the species between the two periods of study, sex and sampling sites, the Fulton condition factor $(K)$ was used (Fulton, 1911, in Ricker, 1975). It is derived from the following equation:

$$
K=\left(T W * 10^{3}\right) /\left(S L^{3}\right)
$$

Given that the condition factor can vary according to fish size (Narahara et al., 1985; Gomes \& Agostinho, 1997), and with the aim of detecting this effect initially, the average values of $K$ (considering the total catch) were calculated per standard length class $(i=10 \mathrm{~mm})$.

The existence of differences between the averages of the condition factor by sex, sampling site, and period of study (factors) was determined through a factorial ANOVA. A oneway ANOVA was carried out separately for each factor and a two-way ANOVA for the different combinations of factors (sex - site, sex - period and site - period). This procedure was applied due to the low sample size that prevented a completely balanced three-way design. In order to reduce the probability of type I error, a Bonferroni correction (critical value of $\mathrm{P}=0.02$ ) was applied.

Size distribution per species, sex and period of study were calculated and compared through the association test of Kolmogorov-Smirnof (Sokal \& Rohlf, 1995).

In order to estimate the growth parameters, the von Bertalanffy equation was applied using the age data and SL corresponding to the specimens that presented real growth marks. The parameters were adapted using non-linear regression by means of the iterative method of Marquart (Saila et al., 1988) (Statgraphics - Graphics Software Systems, Inc., 1990). The parameters of the following equation were adjusted for both sexes:

$$
L_{t}=L_{\infty}\left(1-e^{-k(t-t o)}\right)
$$

where: $L_{t}=$ standard length at age $t ; L_{,}=$asymptotic length of the growth curve; $k=$ growth coefficient; and $t_{0}=$ hypothetical age at which growth begins.

The growth equation in weight was calculated deductively from the length-weight relationship and the growth equation in length, both described previously.

The value of the asymptotic weight $(W$,) was obtained by substituting asymptotic length $(L$,$) in the equation:$

$$
W t_{\infty}=a * L_{\infty}^{b}
$$

with $W$, being the maximum total weight that the individuals could have reached if they had lived in ideal environmental conditions. Therefore, the growth curve in weight is defined by the equation:

$$
W t=W_{\infty}\left[1-e^{-k(t-t o)}\right]^{b}
$$

The equation proposed by Ssentongo \& Larkin (1973) was used to calculate total mortality.

$$
Z=\left(k *(n \div(n+1)) *\left(\ln \left[\left(L_{\infty}-l_{c}\right) \div\left(L_{\infty}-l\right)\right]\right)\right)^{-1} \quad[8]
$$


Table 1. Bimonthly average marginal increment (MI) in scales of L. acutidens. $\mathrm{SD}=$ standard deviation, $\mathrm{N}=$ number of individuals sampled, $\mathrm{T}^{\circ} \mathrm{C}=$ average water temperature during sampling.

\begin{tabular}{ccccc}
\hline Months & MI mm & SD & $\mathbf{N}$ & $\mathbf{T}^{\circ} \mathbf{C}$ \\
\hline January - February & 0.793 & 0.050 & 18 & 28.5 \\
March -April & 0.087 & 0.077 & 25 & 26.1 \\
May - June & 0.037 & 0.023 & 16 & 20.8 \\
July - August & 0.065 & 0.051 & 25 & 19.9 \\
September - October & 0.060 & 0.058 & 34 & 20.6 \\
November - December & 0.074 & 0.074 & 75 & 27.7 \\
\hline
\end{tabular}

where: $Z=$ total mortality; $n=$ total number of individuals caught; $l_{c}=$ shortest catch length; and $l=$ average catch length.

The determination of natural mortality $(M)$ was calculated following the equation of Pauly (1980):

$\log M=-0.0066-0.279 \log L_{\infty}+0.6543 \log k+0.4634 \log T$

According to Sparre et al. (1990), the calculation of $M$ using this formula belongs to the category of "qualified conjectures". However, when no other information is available about $M$, as is almost always the case, it could be applied.

In order to determine fishing yield, the model of yield per recruit by Beverton \& Holt (1957) was used. The equation used for its calculation was as follows:

$Y / R=F \exp [-M(T c-T r)] * W_{\infty} *\left((1 \div Z)-(3 S \div Z+k)+\left(3 S^{2} \div Z+2 k\right)-\left(S^{3} \div Z+3 k\right)\right]$

[10]

where: $S=\exp \left[-k\left(T_{c}-t\right)\right] ; k=$ von Bertalanffy growth parameter; $t_{o}=$ hypothetical age of von Bertalanffy growth; $T_{c}=$ age at first capture; $T_{r}=$ minimum age at which the fish can be included in the fishery; $W_{,}=$asymptotic body weight; and $F=$ fishing mortality. The value of fishing mortality was obtained by replacing the values previously obtained from natural mortality $(M)$ and total mortality $(Z)$ in $Z=F+M$.

\section{Results}

The interpretation of the growth rings of the scales presented difficulties because a number of samples had false marks or the rings were very close together (doubles). Thus, $45 \%$ of the scale samples had to be discarded.

The bimonthly average values of the marginal increment $(M I)$ and its standard deviations are presented in Table 1. The lowest recorded values were from May to June. The mark is considered single and annual.

According to the results obtained from the multiple regression, there is a significant relationship $(\mathrm{P}<0.05, \mathrm{n}=20)$ and a positive simple partial correlation $(0.55)$ between temperature and $M I$. On the other hand, the same variable had no correlation (-0.07) to hydrometric level.

Based on the grouping of the $M I$ data per study period and season, the post-filling period (Fig. 3) had the lowest $M I$ value in winter-spring. The ANOVA showed that there were not significant differences in the $M I$ between periods $(\mathrm{P}<$ $0.05)$, but they were significant between seasons $(\mathrm{P}<0.05$, d.f. $=3,189$ ). The a posteriori multiple comparisons (Tukey) revealed that these differences were significant only between summer and autumn.

Ages ranged from one to nine, with age five being the most frequent in the first phase and age four during the second (Fig. 4).

Average standard length by age and sex is presented in Table 2. Although females were on average larger than males of the same age (except at age two), significant differences were only detected at two and three years of age $(t$ test, $\mathrm{P}<0.05)$.

The results of the length/weight relationships by sex and period are presented in Table 3. According to the confidence intervals, the calculated value $b$ for males was significantly lower than three in the first study period, but not significantly different during the second one. In females, value $b$ was not significantly different from three during the first study

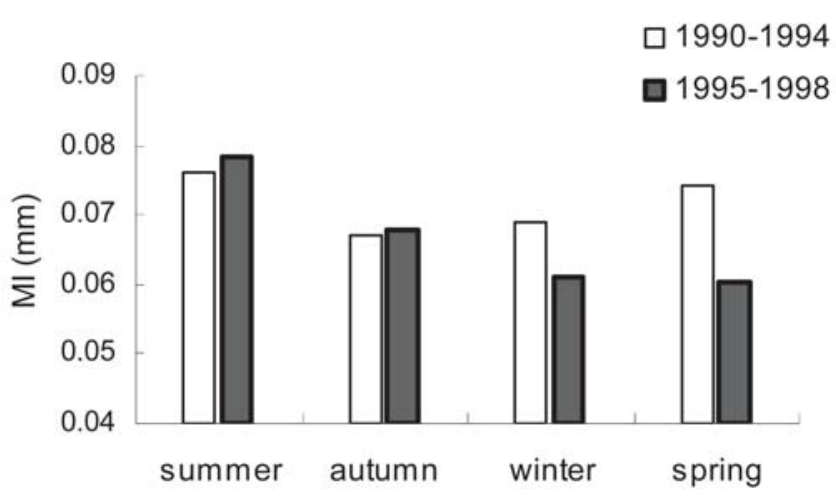

Fig. 3. Season and study period variation in the average marginal increment (MI) of L. acutidens. First period: 1990-1994, second period: 1995-1998.

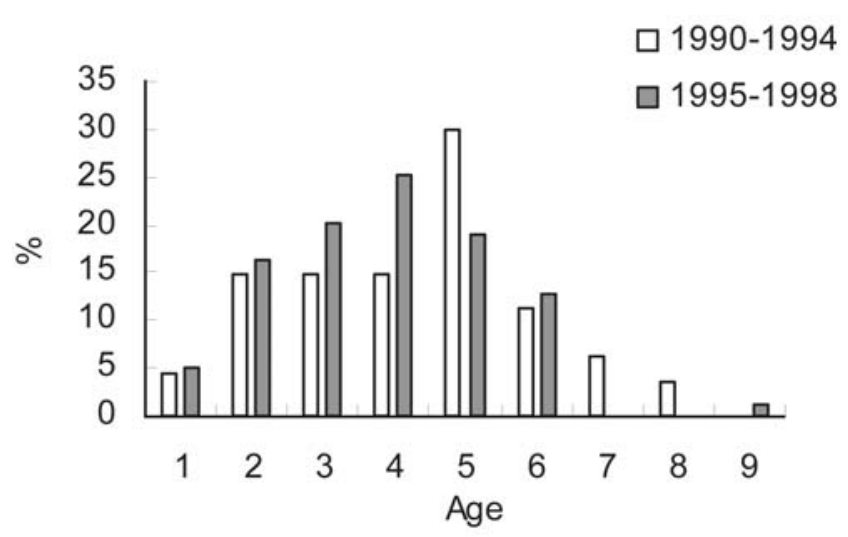

Fig. 4. Age structure of L. acutidens compared by study period. 
Table 2. Age and sex structure of $L$. acutidens. $\mathrm{N}=$ number of individuals sampled, $\mathrm{SL}=$ standard length $(\mathrm{mm}) \mathrm{SD}=$ standard deviation. In order to compare sizes of males and females, the $t$ test of unpaired samples was used. Significant results $(\mathrm{P}<0.05)$ are emphasized with an asterisk.

\begin{tabular}{lllllllll}
\hline & \multicolumn{7}{c}{ FEMALES } & \multicolumn{7}{l}{ MALES } \\
\hline AGE & N & \% & SL & SD & N & \% & SL & SD \\
\hline 1 & 5 & 4.2 & 148 & 13.68 & 2 & 3.78 & 139 & 22.63 \\
2 & 14 & 11.9 & 148 & 19.68 & 14 & 26.42 & 170 & 27.60 \\
3 & 16 & 13.6 & 200 & 17.60 & 15 & 28.30 & 184 & 13.94 \\
4 & 23 & 19.5 & 212 & 22.89 & 8 & 15.09 & 211 & 15.82 \\
5 & 36 & 30.5 & 234 & 27.99 & 8 & 15.09 & 224 & 29.92 \\
6 & 15 & 12.7 & 247 & 23.19 & 7 & 13.21 & 242 & 15.15 \\
7 & 5 & 4.2 & 260 & 28.62 & 1 & 1.89 & 254 & - \\
8 & 4 & 3.4 & 269 & 16.50 & - & - & - & - \\
9 & 1 & - & 295 & - & - & - & - & - \\
\hline
\end{tabular}

period, but it was significantly higher during the second.

The comparison of the length/weight relationship curves through analysis of covariance, considering standard length as a covariable, total weight the dependent variable, sex and period as independent variables (factors), and using the $a$ priori test of parallelism, demonstrates a significant difference $(\mathrm{P}<0.05$, d.f. $=1,721)$ between the slopes $(b)$ of males and females, with those of the females being higher. The differences were not significant for the curves between study periods $(\mathrm{P}<0.05$, d.f. $=1,811)$.

Individuals smaller than $130 \mathrm{~mm}$ presented a marked variation in the condition factor $K$ compared to the standard length classes (Fig. 5). Therefore, to avoid biases, specimens larger than the aforementioned ones were used in the temporal analysis of the condition factor. The bimonthly average values of $K$ grouped by study period, site and sex, are presented in Table 4.

Several two-way ANOVAs were done with the condition factor as the dependent variable and sex and site as independent variables. In another analyses, period and sex were the independent variables. In the first ANOVA, the only significant difference occurred between sampling sites $(\mathrm{P}<0.05$, d.f. $=3,717)$. The lowest average value of $K$ was recorded in Puerto Valle and the highest in Puerto Júpiter, both found within the lentic area of the reservoir, with the latter being closer to the dam. The second ANOVA indicated significant differences in $K$ between study periods, with an increase during the post-filling period $(\mathrm{P}<0.05$, d.f. $=11,680)$. No significant differences were found between sexes.

The condition factor showed variations in both sexes over the year. Peaks were recorded for the females in February, April and June, with sustained elevated values from August to October, when they decreased for both sexes (Fig. 6).

The average standard length of the total female catch was $196 \mathrm{~mm}$, with the maximum being $305 \mathrm{~mm}$ and the minimum 98 $\mathrm{mm}(\mathrm{n}=426, \mathrm{SD}=47.47)$. The males presented an average standard length of $174 \mathrm{~mm}$, with a minimum of $92 \mathrm{~mm}$ and a maximum of $305 \mathrm{~mm}(\mathrm{n}=297, \mathrm{SD}=41.96)$.

The size distribution was polymodal for both sexes (Fig. 7). Significant statistical differences $(\mathrm{P}<0.001)$ were demonstrated (Kolmogorov-Smirnof test) in the size distribution of males and females and by study period. In the second phase (after the damming), smaller-sized individuals of both sexes were more abundant. In turn, the males were differentiated from the females by having a greater proportion of smallersized individuals in both periods.

The von Bertalanffy growth equation obtained for males and females together was the following:

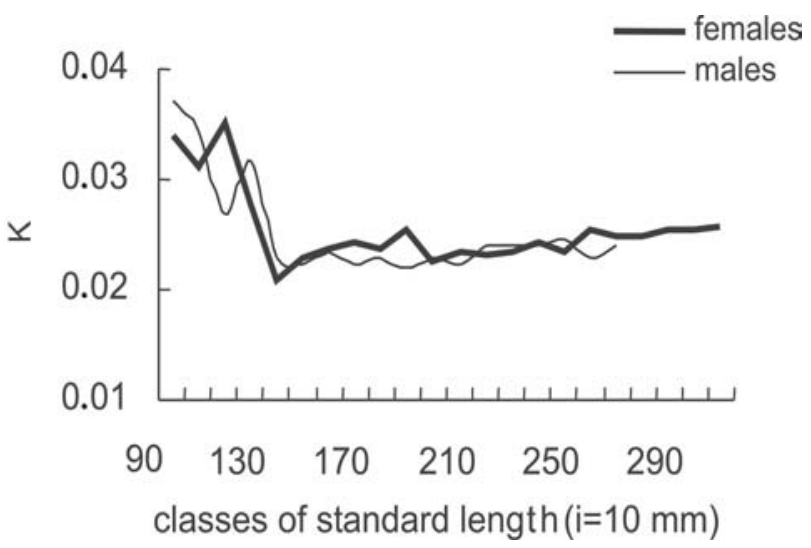

Fig. 5. Relationship of the condition factor $(K)$ by standard length class and sex for L. acutidens.

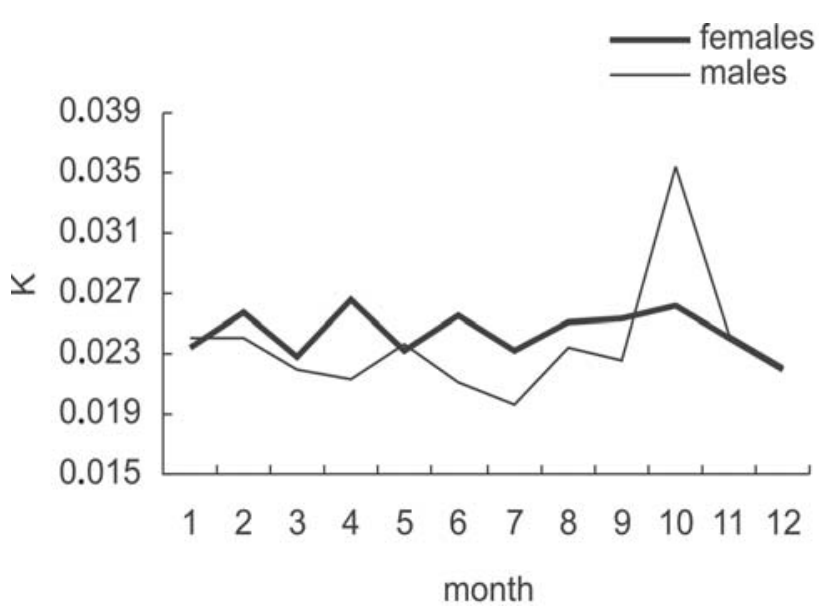

Fig. 6. Monthly average condition factor (K) by sex for $L$. acutidens.

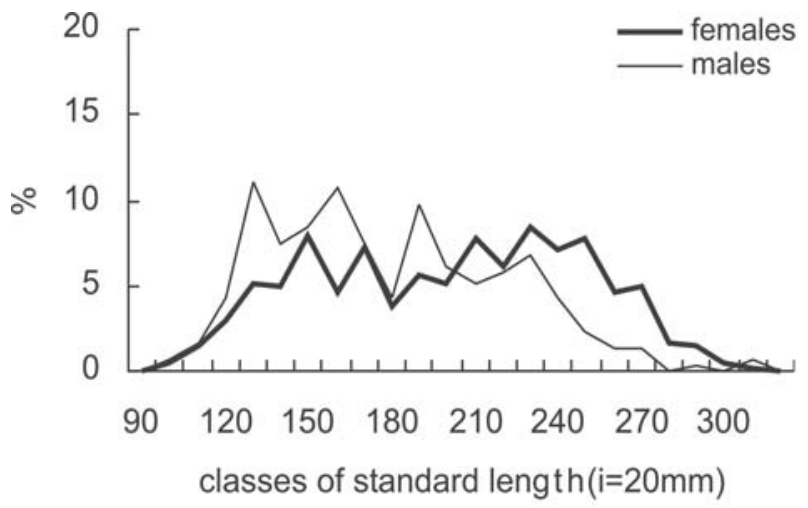

Fig.7. Size distribution by standard length classes and sex for L. acutidens. 
Table 3. Length-weight relationship of $L$. acutidens. $\mathrm{M}=$ males, $\mathrm{F}=$ females, $\mathrm{CI}=95 \%$ confidence interval, $a$ and $b=$ regression parameters, $r=$ Pearson correlation coefficient, $\mathrm{N}=$ number of individuals in the sample. Asterisks denote significant differences of coefficient $b$ from 3 according to a one-sample, two-tailed $t$-test (see text for details).

\begin{tabular}{|c|c|c|c|c|c|c|c|c|c|}
\hline & \multicolumn{3}{|c|}{ 1990-1994 } & \multicolumn{3}{|c|}{ 1994-1998 } & \multicolumn{3}{|c|}{ 1990-1998 } \\
\hline & M & $\mathbf{F}$ & $M$ and $F$ & $\mathbf{M}$ & $\mathbf{F}$ & $M$ and $F$ & M & $\mathbf{F}$ & $M$ and $F$ \\
\hline$a$ & $1.110^{-4}$ & $2.110^{-5}$ & $1.110^{-4}$ & $1.610^{-5}$ & $0.910^{-5}$ & $1.110^{-3}$ & $5.410^{-5}$ & $1.210^{-5}$ & $3.210^{-5}$ \\
\hline$b$ & $2.72 *$ & 3.03 & $2.72 *$ & 3.08 & $3.19 *$ & $3.16^{*}$ & 2.84 & $3.13 *$ & 2.94 \\
\hline CI & 2.50 & 2.79 & 2.55 & 2.97 & 3.02 & 3.09 & 2.74 & 3.02 & 2.87 \\
\hline $95 \%$ & 2.93 & 3.27 & 2.89 & 3.18 & 3.31 & 3.24 & 2.95 & 3.24 & 3.02 \\
\hline$r$ & 0.93 & 0.93 & 0.92 & 0.98 & 0.97 & 0.97 & 0.96 & 0.96 & 0.95 \\
\hline $\mathbf{N}$ & 104 & 148 & 274 & 193 & 278 & 539 & 297 & 426 & 813 \\
\hline
\end{tabular}

Table 4. Average values of condition factor $(K)$ of $L$. acutidens per site, sex and period of study. $\mathrm{n}=$ number of individuals, $S D$ = standard deviation, $\mathrm{F}=$ females, $\mathrm{M}=$ males, $\mathrm{N}=$ sampling size, $\mathrm{VLL}=$ Puerto Valle, $\mathrm{JPT}=$ Puerto Júpiter, $\mathrm{NPM}=\mathrm{Nemesio}$ Parma, YBY = Yabebiry.

\begin{tabular}{|c|c|c|c|c|c|c|c|c|c|c|c|c|}
\hline & \multicolumn{3}{|c|}{ F (1990-1994) } & \multicolumn{3}{|c|}{ М(1990-1994) } & \multicolumn{3}{|c|}{$F(1995-1998)$} & \multicolumn{3}{|c|}{ М(1995-1998) } \\
\hline & $K$ & SD & $\mathbf{N}$ & $\boldsymbol{K}$ & SD & $\mathbf{N}$ & $\boldsymbol{K}$ & SD & $\mathbf{N}$ & $\boldsymbol{K}$ & SD & $\mathbf{N}$ \\
\hline NPM & 0.026 & 0.015 & 83 & 0.026 & 0.022 & 52 & 0.025 & 0.005 & 20 & 0.025 & 0.005 & 75 \\
\hline VLL & 0.024 & 0.003 & 47 & 0.022 & 0.003 & 23 & 0.022 & 0.008 & 126 & 0.022 & 0.002 & 69 \\
\hline JPT & $\ldots$ & $\ldots$ & $\ldots$ & $\ldots$ & $\ldots$ & $\ldots$ & 0.025 & 0.003 & 36 & 0.027 & 0.017 & 20 \\
\hline
\end{tabular}

$S L=338 \quad\left\{1-e^{-0.16(t-(-2.1))}\right\}$

The estimated value of total mortality was $Z=0.3663$ years ${ }^{-1}$, using $l c=140 \mathrm{~mm}$ (average length at age 1 ) and total catch average $l=210 \mathrm{~mm}$. Natural mortality was $M=0.25$ years $^{-1}$ and fishing mortality $F=0.1163$ years $^{-1}$.

In order to obtain the Beverton \& Holt's yield per recruit, $W_{,,}=816.13 \mathrm{~g}$ and $t_{c}=1.5$ years were used, obtaining a value of $Y / R=57.2 \mathrm{~g}$ per recruit, applying a fishing mortality of 0.1163 years $^{-1} . F$ was graphically represented as a function of $Y / R$ (Fig. 8).

\section{Discussion}

The formation of growth marks on calcified structures is associated with environmental variables such as temperature, photoperiod, and food availability (Fagade, 1974; Sparre et al., 1990). It is also related to seasonal changes of rainy and dry periods (Boujard et al., 1991).

The abiotic factor associated with the formation of growth

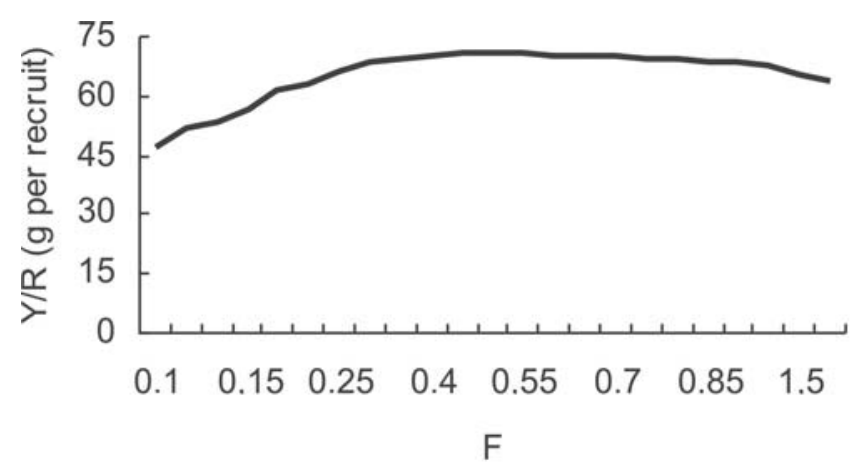

Fig. 8. Beverton and Holt's yield-per-recruit curve for $L$. acutidens. marks in this study was just temperature, associated to photoperiod (Fontoura \& Agostinho, 1996), not hydrometric level. In this way, in the phase before the formation of the reservoir, the lowest values of the marginal increment (average) were recorded in winter and autumn. In the second period, the lowest average values of the marginal increment shifted to spring. In the latter case, it may be supposed that the delay in the low growth period and consequent formation of the annual ring was associated with diet changes after dam closure. During the first years after closing, impoundments present high abundance of small fishes (Agostinho et al., 1999), ensuring winter food availability. During this time, this species forages opportunistically on this resource ( $>75 \%$; Luz-Agostinho et al., 2006; Pereira et al., 2007). During the spring, at the beginning of the spawning period (November to January; Hirt \& Flores, personal communication), the reduction of the availability of small fish (prey growth) and the demand from gonads maturation can be related to low growth and ring formation. An association between reproduction and annual ring formation has been reported by Barbieri \& Santos (1988) in L. friderici in Lobo Dam (Brazil) and by Godoy (1975) in $L$. copelandii $(=$ L. friderici) in the Mogi Guaçu River.

The ages found ranged between one and nine years old. Barbieri \& Santos (1988) recorded a smaller range in Lobo Dam. They reported females up to seven years of age and males up to six. Souza Braga (2001) recognized a nine-yearold female as the oldest specimen in the Volta Grande Dam (Minas Gerais, Brazil).

The age structure of $L$. acutidens in the period after the filling of Yacyretá Reservoir was characterized by the presence of abundant young individuals. This indicated a positive response from the studied population, which tended to remain and expand in the new environment in spite of having initiated the colonization of the reservoir with relatively few individuals per species (mainly upstream migrants) (Oldani et al., 1992). 
The length-weight ratio was not constant in the two study phases. After impoundment, males and females were heavier, suggesting that the new environment was favorable for increasing the nutritional condition. The $b$ value of this relationship showed that females had an isometric and allometric positive before and after dam closure, respectively. In contrast, males changed from allometric negative to isometric, between pre- and post- impoundment. Differences between sexes were observed by Santos \& Barbieri (1991) in L. piau at Tres Marias Dam, while the isometric trend was recorded for L.friderici (=L. acutidens) in Lobo Dam by Barbieri \& Garavello (1981). Downstream of the Yacyretá Dam, the b value for L. acutidens was estimated as 3.167 in a similar study period (Bechara et al.,1999).

The condition factor presented fluctuations during the year, which could reflect the period and duration of the reproductive cycle (Narahara et al., 1985) or the nutritional state in relation to the environmental factors (Le Cren, 1951; Gomes \& Agostinho, 1997). L. acutidens presented the highest $K$ values in February and March (period of post-spawning and maximum temperatures). The authors described a comparable response in a closely related species, L. obtusidens, in the same reservoir (Araya et al., 2005). In addition, the highest values of condition factor $(K)$ were obtained at Puerto Júpiter (reservoir region) during the post-filling phase. This fact could be due to the greater availability of nutrients and increased productivity that occur shortly after reservoir filling (Agostinho et al., 1999).

Ralston (1985) commented that although the von Bertalanffy growth equation has been the most applied model in studies of fish population dynamics, it does not explain the growth of the fish in early life stages. However, the present study corresponds mostly to the final stages of growth, in which the von Bertalanffy equation is applicable in most cases (Ricker, 1975). On the other hand, the growth parameters of this model have physiological significance (Beverton \& Holt, 1957) and vary according to the environmental conditions. They can also vary from one stock to another in the same species, between successive cohorts, and are often different between both sexes.

The growth parameters in this work were calculated using the total catch, due to the lack of sufficient data to fit statistically reliable functions for each period. Infinite length was $327 \mathrm{~mm}$, which is within the length range reported for the species in Lobo Dam by Barbieri \& Santos (1988) in the Mogi Guaçu River. In Volta Grande Dam, Leporinus friderici (=L. acutidens) registered a $L$, of $495 \mathrm{~mm}$ for both sexes together (Souza Braga, 2001).

The observations in this work concerning L. acutidens have indicated that the species has found adequate conditions in the reservoir environment that allow it to successfully carry out its biological functions, given that there is a greater frequency of the smaller size classes in the period after the closing of the dam than in the first, for both sexes. The L. acutidens specimens caught downstream from Yacyretá Dam (Bechara et al., 1999) reached larger sizes than those of the reservoir.

The lack of information about mortality and yield in fluvial fishing prevents a more complete understanding of the population dynamics. The data that have been presented here are the first for the region and the species, and will be very useful for management purposes because they allow an approximation of the state of exploitation of the species. There is no commercial fishing of this species in Yacyretá Reservoir, but it is caught in sport, subsistence, and upstream and downstream experimental fishing (Bechara et al., 1999). One possible reason to explain the low fishing mortality is that this species may be confounded with L. obtusidens, a larger species with higher fishing mortality (Araya et al., 2005). Due to its smaller size, individuals of $L$. acutidens captured are frequently below the minimum size allowed for L. obtusidens according to present regulations in Argentina and Paraguay (45 cm in total length; Bechara, Pers. Obs.). The low variation of the estimated yield per recruit according to increasing fishing mortality ahead of the observed values $(\mathrm{F}=0,12)$ was also observed by Mateus \& Petrere Jr (2004).

In summary, this work shows that during the first years after the filling of the Yacyretá Reservoir, L. acutidens reached better condition factor and recruitment compared with the pre-filling phase, and the period of the growth ring formation shifted from winter to spring. There were differences in length/ weight relationships. During the whole study period, this species exhibited low fishing mortality and was underexploited by commercial and recreational fisheries.

\section{Acknowledgment}

We thank Jaime Luiz Lopes Pereira for preparing the study area map.

\section{Literature Cited}

Agostinho, A. A., L. Miranda, L. Bini, L. Gomes, S. Thomaz \& H. Suzuki. 1999. Patterns of colonization in neotropical reservoirs and prognoses on aging. Pp. 227-265. In: Tundisi, J. \& M. Straskraba (Eds.). Theoretical reservoir ecology and its applications. São Paulo, 592p.

Agostinho, A. A., L. C. Gomes, S. Veríssimo \& E. K. Okada. 2004. Flood regime, dam regulation and fish in the Upper Paraná river: effects on assemblage attributes, reproduction and recruitment. Reviews in Fish Biology and Fisheries, 14:11-19.

Agostinho, A. A., L. Gomes \& F. Pelicice. 2007. Ecologia e Manejo de Recursos Pesqueiros em Reservatórios do Brasil. Eduem (Ed.), Maringá, 501p.

Andrian, I., C. Dora, G. Torrente \& C. Ferretti. 1994. Espectro alimentar e similaridade na composição da dieta de quatro espécies de Leporinus (Characiformes, Anostomidae) do rio Paraná $\left(22^{\circ} 10^{\prime}-22^{\circ} 50 \mathrm{~S} / 53^{\circ} 10^{\prime}-53^{\circ} 40^{\prime} \mathrm{W}\right)$ Brasil. UNIMAR, 16(3): 97-106.

Araya, P., A. A. Agostinho \& J. A. Bechara. 2005. The influence of dam construction on a population of Leporinus obtusidens (Valenciennes, 1847) (Pisces, Anostomidae) in the Yacyreta Reservoir (Argentina). Fisheries Research, 74: 198-209. 
Barbieri, G. \& E. Santos. 1988. Análise comparitiva do crescimento e de aspectos reprodutivos da piava, Leporinus friderici (Blach, 1794) (Osteichthyes, Anostomidae) da represa do Lobo e do rio Moji-Guaçu, Estado de Säo Paulo. Ciência e Cultura, 40(7):693-397.

Barbieri, G. \& J. C. Garavello. 1981. Sobre a dinâmica da reprodução e da nutrição de Leporinus friderici (Bloch, 1794) na represa do Lobo. Brotas, Oitirapina, SP (Pisces, Anostomidae). II Seminário Regional de Ecologia, (UFSCar, São Carlos): 347-387.

Bechara, J., S. Sánchez, J. Roux, J. Terres \& C. Flores Quintana. 1999. Variaciones del factor de condición relativo de la ictiofauna del río Paraná aguas debajo de la represa de Yacyretá, Argentina. Revista Ictiología 7 (Número Especial) 75-89.

Bervian, G. \& N. F. Fontoura. 2006. Estatistic model of variable allometric growth in Micropogonias furnieri (Actinopterygii, Scianidae). Journal of Fish Biology, 68(1):196-208.

Beverton, R. \& S. Holt. 1957. On the dynamics of exploited fish populations. Fish Ministry of Agriculture, Fisheries and Food, Fishery Investigations 19, London, 533p.

Bonetto, A. A. 1986. The Paraná River System. Pp. 541-556. In: Davies, B. R. \& K. F. Walker (Eds.). The ecology of river systems. The Netherlands, $620 \mathrm{p}$.

Boujard, T., F. Lecome, J. Renno, F. Meunier \& P. Neveu. 1991. Growth in four populations of Leporinus friderici (Bloch, 1794) (Anostomidae, Teleostei) in French Guiana. Journal of Fish Biology, 38:387-397.

Braga, L. 1993. Los Anostomidae (Pisces Characiformes) de Argentina. FAUNA de agua dulce de la Argentina, 40(3):31-33.

Fagade, S. O. 1974. Age determination in Tilapia melanotheron (Ruppell) in the Lagos Lagoon, Lagos, Nigeria. Pp. 71-7. In: Bagenal, T. B. (Ed.). The ageing of fish. England, 254 p.

Fontoura, N. F. \& A. A. Agostinho. 1996. Growth with seasonally varying temperaturas: an expansion of the von Bertalanffy growth model. Journal of Fish Biology, 48(4):569-584.

Garavello, J. C. 1979. Revisão taxonômica do gênero Leporinus Spix, 1829 (Ostariophysi, Anostomidae). Unpublished Ph.D. Thesis, Universidade de São Paulo, São Paulo. 175p.

Garcia, O. 1999. Principales características de la central hidroeléctrica de Yacyretá, Argentina, y de los ambientes de su área de influencia en relación con los programas de evaluación de la fauna íctica. Revista de Ictiología, 7:5-14.

Godoy, M. P. 1975. Peixes do Brasil. Subordem Characoidei da Bacia do río Mogi Guaçu. Piracicaba. Franciscana (Ed.). Piracicaba, 846p.

Gomes, L. C. \& A. A. Agostinho. 1997. Influence of the flooding regime on the nutritional state and juvenile recruitment of the curimba, Prochilodus scrofa, Steindachner, in upper Paraná River, Brazil. Fisheries Management and Ecology, 4:263-274

Heald, E. J. \& R. C. Griffiths. 1967. La determinación, por medio de la lectura de escamas, de la edad de la sardina, Sardinella anchovia, del Golfo de Cariaco, Venezuela Oriental. Serie Recursos Explotación Pesquera, 10: 377-421.

King, M. 1995. Fisheries biology assessment and management. Fishing News Book. Oxford, 341p.

Le Cren, E. D. 1951. The length-weight relationship and seasonal cycle in gonad weight and condition in the perch (Perca fluviatilis). Journal of Animal Ecology, 20:201-219.
Lopes, C. A., E. Benedito-Cecilio \& A. A. Agostinho. 2000. The reproductive strategy of Leporinus friderici (Characiformes, Anostomidae) in the Paraná River basin: effect of reservoirs. Revista Brasileira de Biologia, 60(2):255-266.

Luz-Agostinho, K. D. G., L. M. Bini, R. Fuji, A. A. Agostinho \& H. F. Julio Jr. 2006. Food spectrum and trophic structure of the ichthyofauna of Corumbá reservoir, Paraná river Basin, Brazil. Neotropical Ichthyology, 4(1):61-68.

Mateus, L. A. F. \& M. Petrere Jr. 2004. Age, growth and yield per recruit analysis of the pintado Pseudoplatystoma corruscans (Agassiz, 1829) in the Cuiabá River basin, Pantanal Matogrossense, Brazil. Brazilian Journal of Biology, 64(2):257-264.

Matsuura, S. 1961. Age and growth of flatfish, Ganza - birame, Pseudorhombus cinnamoneus (Temminck et Schelegel). Records of Oceanographic Words in Japan, 5:103-110.

Narahara, M. Y., H. M. Godinho, N. Fenerich-Verani \& E. Romagosa. 1985. Relação peso-comprimento e fator de condição de Rhamdia hilarii (Valenciennes, 1840) (Osteichthyes, Siluriformes, Pimelodidae). Boletin del Instituto de Pesca, 12(4):13-22.

Nilsson, C., C. Reidy, M. Dynesius \& C. Revenga. 2005. Fragmentation and flow regulation of the World's large river systems. Science, 308(5720):405-408.

Oldani, N. O., J. M. Iwaszkiw, O. H. Padín \& A. Otaegui. 1992. Fluctuaciones de la abundancia de peces en el Alto Paraná (Corrientes, Argentina). Publicaciones de la Comisión Administradora del Río Uruguay. Serie Técnico-Científica, 1:43-55.

Okada, K. O., A. A. Agostinho, M. Petrere Jr. \& T. Penczak. 2003. Factors affecting fish diversity and abundance in drying pools and lagoons in the upper Paraná river basin, Brazil. Ecohydrology \& Hydrobiology, 3(1):97-110.

Pauly, D. 1980. A selection of simple methods for the assessment of tropical fish stocks. FAO Fish. Circ. 729, 54 p.

Payne, A. I. 1976. The determination of age and growth from the scales in Barbus liberiensis (Pisces, Cyprinidae). Journal of. Zoology, 180:455-465.

Pereira, A. L., E. Benedito \& C. M. Sakuragui. 2007. Spatial variation in the stable isotopes of ${ }^{13} \mathrm{C}$ and ${ }^{15} \mathrm{~N}$ and trophic position of Leporinus friderici (Characiformes, Anostomidae) in Corumbá Reservoir, Brazil. Anais Academia Brasileira de Ciências, 79(1):41-49.

Petry, A. A., A. A. Agostinho \& L. Gomes. 2003. Spatial variation of the fish assemblage structure from the upper Rio Paraná floodplain, Brazil, in de dry year. Acta Limnologica Brasileira, 15(1):1-13.

Petts, G. E. 1984. Impounded rivers. Perspectives for ecological management. John Wiley \& Sons, (Eds.). Chichester, 319p.

Ralston, S. A. 1985. A novel approach to aging tropical fish. ICLARM. Newsletter, 8(1):1-49.

Ricker, W. W. 1975. Computation and interpretation of biological statistics of fish population. Bulletin of the Fisheries Research Board of Canada, 191:1-382.

Saila, S., C. Recksier \& M. Prager. 1988. Basic fishery science programs. Elsevier. New York, 231p.

Santos, G. \& G. Barbieri. 1991. Idade e crescimento de Prochilodus marggravii (Walbaum, 1792) (Characiformes, Prochilodontidae) do rio São Francisco, Minas Gerais. Revista Ceres, 38(215):5-16.

Sokal, R. \& F. Rohlf. 1995. Biometry. The principles and practice 
of statistics in biological research. Freeman W. H. \& Co (Eds). San Francisco, 850 p.

Souza Braga, F. M. 2001. Crescimento e mortalidade de Leporinus friderici (Ostariophysi, Anostomidae) na represa de Volta Grande, rio Grande, localizada entre os Estados de Minas Gerais e São Paulo, Brasil. Acta Scientiarum, 23(2): 415420.

Sparre, P., E. Ursin \& S. Venema. 1990. Introducción a la evaluación de stocks de peces tropicales. Parte 1. Manual. FAO. Documento Técnico. Pesca (306.1). Roma, 493 p.

Ssentongo, G. W. \& P. Larkin. 1973. Some simple methods of estimating mortality rates of exploited fish populations. Journal of the Fisheries Research Board of Canada, 30: 695698.

Ward, J. V. \& J. A. Stanford. 1979. The Ecology of Regulated Rivers. Plenum Press. New York, 398p.

Accepted February 2008

Published 31 March 2008 